\title{
NEGATIVE SELF-REGARD AT WORK - FRUSTRATING THE NEED FOR SELF-ENHANCEMENT AND SELF-CONSISTENCY
}

\author{
MARCUS CREDÉ \\ University of Cape Town \\ LINDA PRICE \\ University of Cape Town
}

\begin{abstract}
A positive and consistent sense of self is a key requirement for psychological well-being. Thirteen South African police officers and five police psychologists were interviewed to investigate the prevalence of negative social feedback received by officers and the consequences of such feedback on their sense of self. Negative social feedback and perceived lack of support from police management, courts, and government were widely prevalent and were seen to impact strongly on police officers. Officers had a largely negative view of themselves, their organisation, and the social context in which they operated. They engaged in dysfunctional and self-destructive behaviour and experienced significant discrepancies between their work and non-work selves.
\end{abstract}

\section{OPSOMMING}

'n Positiewe en konsekwente self-bewussyn is 'n sleutelvereiste vir sielkundige welsyn. Onderhoude is met dertien polisie-beamptes en vyf sielkundiges van die Suid-Afrikaanse Polisiediens gevoer ten einde die voorkoms van negatiewe sosiale terugvoer deur offisiere en die gevolge van sodanige terugvoer te ondersoek. Negatiewe sosiale terugvoer en die waargenome gebrek aan ondersteuning van polisie-bestuur, howe en die regering was wyd teenwoordig en impakteer sterk op polisie-beamptes. Beamptes het grootliks 'n negatiewe beeld gehad van hulself, hulle organisasie en die sosiale konteks waarin hulle opereer. Hulle het in disfunksionele en self-gerigte destruktiewe gedrag verval en het beduidende gapings ervaar tussen hulle werk self en hulle nie-werk self.

Work defines not only what we do but also, to a large degree, what and who we are (Hulin, 2002). In addition to spending a large part of our waking lives engaged in work activities, we also describe ourselves to others in terms of our work and even our names often refer to occupations and work (Shreuder and Theron, 1997). In addition, we construct our own definitions of ourselves around our work. Work and occupational meaning is important in the creation of both personal meaning (Brief \& Nord, 1990; Neikrug, 1982; O'Brien, 1992) and overall identity (Hochschild, 1981; Shamir, 1986; Sheeran \& Abraham, 1994) inasmuch as they supplement the identity and global sense of self that arises from our interactions with friends and family (Burr, 1995; Girodo, 1984; Goffman, 1959; O'Brien, 1992). As Casey (1995) notes: "In modern society individuals have defined themselves, and in turn, have been socially defined, by the type of work that they do in the public sphere" (p. 28). In a world in which the boundary between work and non-work has become increasingly hazy (temporally, socially, and spatially) our work-based identity and sense of self becomes increasingly important. Indeed: "it is in these roles that we know each other; it is in these roles that we know ourselves" (Park, 1936, in McCall, 1987, p. 134).

Work becomes an extension of the self for three key reasons (Rosenberg, 1979). There is the subjective experience of work belonging to "me" or of being "mine"; the attachment to work of feelings of pride or shame; and, thirdly, introjection, a process that occurs when the individual sees the fate of his/her work and the fate of his/her self to be intertwined. Moreover, individuals seek social relationships and a sense of purpose and enhancement of the self-concept from work (Levi, 1981; Locke $\&$ Taylor, 1990; Nord, Brief, Atieh, \& Doherty, 1990). Job content can thus significantly determine intellectual style; depression; self-competence; belief in internal and external control; and desires or needs for self-direction (O'Brien, 1992). For Sorokin (1927, in Casey, 1995, p. 81) the impact of work runs even deeper - "all psychological processes of any member of an occupation undergo modification ... greater is the occupational influence on the processes and on the character of one's evaluations, beliefs, practical judgments, opinions, ethics, and whole ideology".

Requests for copies should be addressed to: L Price, School of Management

Studies, University of Cape Town, Private Bag, Rondebosch, 7700
Given the importance of our work experiences and work lives to our self-definition it is of interest to ask what impact an explicitly hostile and negative work environment would have on the individual. Such contexts are relatively rare. While almost every job is characterized by elements that are negative, undesirable, or unpleasant, there are few in which the negative and undesirable predominates. Even fewer are those in which there is little social support to compensate for the negative elements; in which the employee does not perceive the opportunity to leave that particular job and seek alternate employment; and in which an entire strata of employees is affected. Police officers however often operate in just such work environments, characterized not only by high levels of stress but also by interactions with the public that are often particularly hostile in nature. This is particularly the case in South Africa where police officers continue to operate in a social environment in which the police officer is viewed with great hostility, fear, and suspicion.

\section{THE NATURE OF POLICE WORK}

Police work has consistently been found to be among the most stressful occupations, primarily because of the long working hours, dangerous working conditions, and the almost daily confrontation with high degrees of physical danger, violence, and trauma. In addition, police interact with a population that is, at best, fearful and, at worst, insulting and abusive (e.g. Alkus \& Padesky, 1980; Burke, 1993; Violanti, 1992; Violanti \& Aron, 1994; Violanti \& Marshall, 1983; Waters \& Martelli, 1989). Such negative feedback comes not only from the criminal elements within communities but also from minority groups (Belson, 1975), social workers, and lawyers (Flanagan \& Vaughn, 1996). Interestingly, even when compared to other, seemingly similarly stressful occupational groups such as firefighters and emergency medical technicians, police officers (and probation officers and prison guards) experience significantly higher levels of emotional exhaustion, depersonalisation, and chronic stress (Anson \& Bloom, 1988). This is partly the result of frequent contact with an unpredictable and hostile public and an indifferent police bureaucracy. 


\section{The South African Context}

South African police officers are, in addition, confronted with the Apartheid related stigma that is attached to police work. In South Africa the strength of negative sentiment toward the police is firmly rooted in the past, primarily the events of the 1980s when political organisations such as the African National Congress, the United Democratic Front, and trade unions launched a concerted effort to end the Apartheid State. In response, the South African government virtually outlawed extra-parliamentary opposition, introduced detention without trial, and sent both the army and police into the townships with almost unlimited powers to quell the resistance (Nathan, 1989). The result was that the police became associated with the disruption of meetings, detention of community leaders, the violent dispersal of marches and funerals, the targeting of religious, cultural, and civic organisations, random house-tohouse searches and the torture and harassment of political activists (Albert, 1978; Anstey \& Stanley, 1994; Berold, 1999; Coleman, 1999; Melville, 1999; Nathan, 1989; Nel \& Steyn, 1997). Goldstone (1994), Melville (1999); Rauch, Levin, Lue, and Ngubeni (1995); and Van Eyk (1993) speak of a mistrust and hatred of the police by many communities that can be attributed to memories of police activities during the Apartheid period (Cook, 1986).

Revelations about police activities during the Apartheid era at the Truth and Reconciliation Commission have reinforced the negative memories associated with the police and thereby strengthened this negative sentiment. Newspapers also frequently highlight police brutality and incompetence. A total of 115 leading articles that focused on some negative aspect of the South African Police Services (SAPS) were found within five daily newspapers over a ten month period; while only 30 articles conveyed sympathy towards the police (e.g. Koopman, 1999; Makgalemele, 1999; Vogel, 1999). The topics covered in these negative reports included: police incompetence (e.g. Ensor, 1999; Friedman, 1999; Gifford, 1999; Goko, 1999; Schronen, 1999a); corruption (e.g. Schronen, 1999b); police brutality (e.g. Altenroxel, 1999; Creswell, 1999); racism (Gophe, 1999; Kotlolo, 1999; Maluleke, 1999; Steinberg, 1999); and social problems such as alcoholism (e.g. Merten, 2000).

\section{Consequences of Police Work}

Police work has been linked to a number of negative consequences for police officers including a higher than average prevalence of heart disease, diabetes, cancer, suicide, alcoholism, and divorce as well as high rates of aggression, anxiety (Beutler, Nussbaum, \& Meredith, 1988), lowered self-worth (Stradling, Crowe, \& Tuohy, 1993); deviant behaviour and burnout (Violanti \& Marshall, 1983; Wallace, Roberg, \& Allen, 1985); emotional exhaustion and depersonalization (Burke, 1993; Gaines \& Jermier, 1983); work alienation and detachment (Burke, 1987, 1993); pessimism, neuroticism and low self-confidence (Pestonjee, 1992); moodiness, depression and emotional numbness (Burke, 1987; Hageman, 1982; Sigler \& Wilson, 1988; Nel \& Steyn, 1997).

In South Africa a number of additional consequences present themselves. The hostilities toward the police have not decreased since the start of political transformation in the early 1990s (Goldstone, 1994). 1993 saw a 106\% year-on-year increase in the number of attacks on police officers, while police-deaths rose from 96 to 176 in the same period. A total of 1090 officers were killed in South Africa between 1994 and November 1999 (Nxusani, 1999). In addition, the suicide rate among South African police officers is twelve times as high as among the general population (Nel \& Steyn, 1997) rising from 65 in 1991 to 172 in 1994 (Burgers, 1994; Nel \& Steyn, 1997) while the number of officers boarded for psychological reasons rose from 37 to 540 in the same period. Turnover in the South African Police Services since 1991 has also risen to a massive $10 \%$ per annum (Burgers, 1994), which is surprising given the paucity of alternate forms of employment in the South African economy. While many of these adverse psychological consequences could be argued to be the result of extremely high levels of stress and job dissatisfaction, a deeper understanding of the mechanisms that underlie these unfavorable psychological states could perhaps be obtained from a consideration of the consequences of the consistent, hostile social feedback that characterizes police work in South Africa. Particular attention needs to be given to the manner in which such persistent and pervasive negative social feedback is likely to frustrate the police officer's need for selfenhancement and self-consistency.

\section{The Need for Self-Enhancement}

The realization that individuals have a need for a positive selfconception is, of course, not new, and nor is the realization that feedback from others is key to the manner in which individuals see themselves (James, 1890). James argued that our need for felt relations with others leads us to attach great importance to the regard we receive from others. As social beings, the feedback that we receive from those important to us (i.e. significant others) engenders either negative or positive perceptions of self. Mead (1934), building on the work of Cooley (1902) elaborated on this position by arguing that it is not so much the actual regard of others that shapes our sense of self but rather the perceived regard or "reflected appraisals" of others. It is these reflected appraisals that are internalized by the individual and thereby facilitate the emergence of the self that, in turn, acts to interpret future social interactions. "The self as that which can be an object to itself, is essentially a social structure and it arises in social experience. After a self has arisen, it in a certain sense provides for itself its social experience..." (Mead, 1934, p.140).

Support for the self-enhancement motive is evident at both a theoretical level (e.g. Allport, 1979; Gergen (1971); Jones (1973); Kaplan (1975); Rosenberg (1981); Shotter (1984); and Strauss, (1997), and an empirical level (Baumgardner, Kaufman, \& Cranford ,1990; Cheek \& Hogan, 1983; Doherty \& Schlenker, 1991; Hoorens, 1995; Maddux, Norton, \& Leary, 1988; McFarlin \& Blasovich, 1981; Moreland \& Sweeney, 1984; Nezlek et al, 1997; Pelham \& Hetts, 1999). All these authors argue that positive feedback from others allows the development of a positive sense of self and reduces the experience of negative affect such as sadness, social anxiety, and depression. Alternately, negative regard will not only result in negative affect but will also impact on the sense of self. This argument is summarised by Rosenberg (1979) who maintains that:

However much an individual may like to think of himself attractive, or skilled in some way, in the long run he will actually believe he is so only if this view is substantiated by external evidence. One of the major sources of evidence is the response of others toward us (consensual validation) (p. 48).

The more consensual the feedback, the greater the likelihood that such feedback will impact on the individual's sense of self (Shrauger \& Schoeneman, 1979), even if the feedback is provided by relative strangers (Hortacsu, 1989). The self is however not only developed through social interaction but is also maintained and changed through social processes (Dodds, Lawrence \& Valsiner, 1997). A positive self-concept requires constant validation in order to remain positive (Rosenberg, 1979) since certainty about what and who we are eludes us (Campbell \& Lavallee, 1993). Indeed, "the responses of others are required not only for confirmation but for the lifelong reconfirmation of our working self-hypothesis" (Rosenberg, 1979, p. 49).

This constant validation process implies that behaviour, mood states and feelings are interrelated and that once negative selffeelings are established they may perpetuate themselves in a cyclical manner (Bohrnstedt \& Felson, 1983; Rhodewalt \& Agustsdottir, 1986; Salovey \& Rodin, 1985). This occurs in two possible ways. 
Firstly, past events, positive and negative, are replayed via memory thereby reactivating the corresponding affective and cognitive responses, and in so doing impacting on the self and reconfirming the working self-hypothesis (Mead, 1934; Freeman, 1993). Negative memories are particularly likely to be activated when the individual is in a similar situation to that in which the original negative feedback was received (e.g. the workplace) (Andersen, Reznik, \& Chen, 1997). Secondly, negatively affected self-image is often communicated to others, even if they were not privy to the original situation. Thus, a momentary negative change in the self-concept can be perpetuated via social feedback and may result in a self-fulfilling prophecy mechanism (Rhodewalt \& Agustsdottir, 1986). The duration of an internalised self-concept change is unclear but if one considers that Higgins, Rhodewalt, and Zanna (1979, in Rhodewalt and Agustsdottir) showed that once-off, laboratory-induced changes were sustained for a number of weeks then one can assume that long-term, continuously and naturally occurring negative feedback is likely to result in more long-term changes in the phenomenal self.

The importance of a positive sense of self becomes clearer when one considers that "negative reflected appraisals have been associated with poorer self-evaluation, poorer self-involvement, and greater inconsistency in the self" (Sheeran \& Abraham, 1994, p. 125). Negative reflected appraisals have also been linked to feelings of tension, depression, and distress (Dressler, 1988; Kaplan, 1975); low self-esteem (Crocker \& Blanton, 1999; Jussim et al, 1992; Leary, 1990); hostility, jealousy, loneliness (Baumeister \& Tice, 1990; Leary, 1990); social anxiety (Baumeister \& Tice, 1990; Maddux, Norton, \& Leary, 1988; Leary \& Atherton, 1986; Schlenker \& Leary, 1982); social paranoia (Kramer \& Wei, 1999); and a general negative affective response (Jussim, Yen, \& Aiello, 1995; Moreland \& Sweeney, 1984; Sweeney \& Wells, 1990).

\section{The Self-Consistency Motive}

While the works of both James (1890) and Mead (1934) clearly highlighted the importance of a positive self-concept, both authors also referred to the importance of a consistent selfconcept. "Two separate 'me's' and 'I's', two different selves, result, and that is the condition under which there is a tendency to break up the personality" (Mead, 1934, p.143). The self-consistency motive refers to the need for individuals to form a particular view of themselves, consisting of a congruent set of selfperceptions integrated into a whole (Baumeister, 1982; Gergen, 1965, 1971; Jussim, Yen, \& Aiello, 1995; Lopez, 1982; Spencer, Josephs, \& Steele, 1993; Swann, Griffin, Predmore, \& Gaines, 1987). Individuals are subsequently motivated to seek feedback from interaction partners that is consistent with their established view of themselves (Schafer \& Keith, 1999; Sheer \& Weigold, 1995). Inconsistent feedback cannot easily be assimilated and may lead to the experience of discomfort (Elliot, 1986; Jussim, Yen, \& Aiello, 1995; Gilbert \& Jones, 1986) such as the stress experienced during everyday role transitions (Allen \& van de Vliert, 1984). Individuals with inconsistent selfconcepts tend to experience a higher incidence of psychological distress, mood instability, and a greater tendency to engage in antisocial behaviour than those individuals who possess stable self-concepts (Campbell \& Lavallee, 1993; Rosenberg, 1979).

Interestingly, this motive for self-consistency is also present when the self-conception is negative (Swann et al, 1987). Even a negative self would present the individual with a predictable, and hence desirable, social world. The reason for the apparent contradiction with the self-enhancement motive is that a positive self-conception is primarily an affective need whereas self-consistency is primarily a cognitive need. Individuals with a negative self-concept who receive further negative feedback would appreciate this information at a cognitive level (for being consistent with their own self-view) while finding it to be a negative affective experience (Alloy \&
Lipman, 1992; Shrauger, 1975, in Swann et al., 1987). Individuals with negative self-concepts who receive negative feedback find it to be accurate and self-descriptive but are also: "...more depressed, anxious, and hostile after they received $i t^{\prime \prime}$ (Swann et al, 1987, p. 886).

\section{The Split Self}

If we accept that the self-concept is strongly impacted upon by situational factors such as social feedback then it becomes likely that dissimilar social contexts (e.g. one characterized by positive feedback and one characterized by negative feedback) will produce dissimilar self-concepts; effectively a split self which denies the individual the "perception of sameness" (James, 1890, p. 334). The resultant status inconsistency (Thoits, 1985) does not provide the individual with confirmation of his/her selfhypothesis. One example of how the self can become split in this manner is a constant stressful role transition between work and non-work (i.e. the private and public life), particularly in the absence of social support (Allen \& van de Vliert, 1984; Boyanowsky, 1984; Bruner \& Kalmar, 1998; Elliot, 1986; Hirsch \& Jolly, 1984; Levi, 1981; Scheier \& Carver, 1983; Strasser, 1984; Van de Vliert, 1984).

\section{RESEARCH HYPOTHESIS}

Central to this study was the assumption that interpersonal relationships at the workplace impact on the manner in which the employee (in this case the police officer) experiences both him/herself and the world in which he/she is located. As such, three main research hypotheses have guided this research. Firstly, South African police officers encounter high levels of hostility from the public in the course of their work. Secondly, this negative regard from others impacts negatively on the manner in which they view themselves and their view of the social world in which they are located. Thirdly, this negative regard results in an inconsistent sense of self due to the simultaneous positive regard that they are likely to experience in their relationships with friends and family.

\section{METHODOLOGY}

A qualitative research methodology with non-random sampling was used in this study. As such the emphasis was on understanding and describing the specific experiences of those individuals who participated in the study, rather than on generalizing such experiences to the greater population of South African police officers.

\section{Participants}

Participants comprised 13 police officers (11 males and two females) and five police psychologists (four females and one male), all of who worked in Cape Town, South Africa. All police officers worked in economically disadvantaged areas at five separate police stations. The psychologists worked at the centralised psychological services centre of the SAPS. Convenience sampling was utilized to access all participants. The commanding officers at each police station placed the researchers in contact with individual police officers who had agreed to participate in the research process. Sampling was thus not random, and the results should therefore only be generalized to other police officers with caution. All of the police officers indicated that they had never been in contact with psychologists from the SAPS, and it is therefore likely that the problems described by these officers are not restricted to police officers seeking professional help from psychologists.

\section{Procedure}

The data was collected via semi-structured, one-on-one interviews that each lasted between one and two hours. They 
were conducted at the participants' places of work. A number of reasons dictated the use of semi-structured interviews. The dynamic nature of the self and the tendency for officers to engage in repressive coping mechanisms (Alkus \& Padesky, 1980; Beehr, Johnson, \& Nieva, 1995; Elison \& Buckhout, 1981) implied that it was important to utilise a philosophical framework and methodology that acknowledges the inherently subjective nature of the experience under examination. It also encourages the use of flexible, sensitive and reflexive methods that explore the personal experiences and interpretations that participants attach to events (Miles \& Hubermann, 1994) while at the same time ensuring that stress and potential harm are minimised.

This need to minimise real or perceived harm to participants (Kvale, 1996; Kimmel, 1988; Miles \& Huberman, 1994) dictated that none of the interviews be taped. All participants were assured of the confidentiality and anonymity of the research process, and the researchers carefully explained that they did not work for the SAPS. Nevertheless, all police officers requested that the interviews should not be recorded; expressing the fear that such information would be used against them. As a result the interviewer took extensive notes during the interviews and supplemented these with his memory by writing up detailed reports of the interviews immediately after completion of each one.

This emphasis on emergent meaning also required the interview schedule to remain flexible and therefore contained a broad set of topics that were explored in the course of each interview rather than a formal schedule of questions. Using the interview as a conversation between participant and researcher allows a post-modern construction of knowledge and understanding (Kvale, 1996; Mishler, 1986), and prevents information from being overlooked as may occur when following a rigid interview schedule. A collaborative relationship was established between participant and researcher by allowing the police officer control over the manner in which information was collected that, in turn, facilitated the sharing of sensitive information. Each interview explored a number of broad topics including: reasons for joining the police, daily work experiences, coping mechanisms, perceived support, the nature of policecommunity relationships, work/non-work interactions, and the perception of the media.

\section{Data Analysis}

Data was analysed using the three-level framework proposed by Kvale (1996). The first level refers to the subject's level of understanding and their direct statements. The second level goes beyond the subjects' self-understanding and seeks to encapsulate broader themes while still remaining within the bounds of critical commonsense understanding. The final level is fundamentally theoretical and links the first two levels to established theoretical frameworks. Such interpretation of data implies a hermeneutic approach (Blaikie, 1993, see also Kvale, 1996, p. 48-50).

\section{RESULTS AND DISCUSSION}

The results confirm the hypothesis that negative, hostile social feedback is not only experienced as stressful but also determines the manner in which individuals view themselves; the communities in which they work; the South African Police Services; society as a whole; and their non-work lives. The impact of negative feedback on the quality of the sense of self was manifest in four key ways: the immediate emotional response; changed behavioural patterns; changes in the manner in which individual police officers feel and think about themselves; changes in the manner in which police officers feel and think about the community, the society, and the organisation in which they are employed.

\section{Self-Enhancement}

The immediate affective responses to negative social feedback from the community and media included feelings of anger, fear, and frustration, findings that are similar to those of Alkus and Padesky (1980); Burke (1993); Violanti and Aron (1994); Waters and Martelli (1989). All three of these emotions indicate a short-term change in the manner in which the individual perceives the social context in which he/she is located at that moment. Such momentary changes in the way in which the social world is perceived may, if repeated regularly, become internalised to the degree that police officers experience these emotions whenever they are in a work situation (i.e. become schema triggered expectancies (Andersen, Reznik, \& Chen, 1997))

The behavioural changes reported by police officers (i.e. higher incidence of drinking, smoking, swearing, higher levels of aggressive behaviour; and changes in religious activities) (see also Munshi, 1998), may be interpreted as coping mechanisms, but can also be regarded as changes in the self-conception inasmuch as these officers indicated that they would not previously have engaged in such behaviour. Similarly, the behavioural changes reported by the psychologists, such as increased levels of spousal abuse (see also Marks, 1995), also suggest a change in the self that underlies the behaviour (Rhodewalt \& Agustsdottir, 1986).

Similarly, officers felt that they had undergone significant personal changes since joining the SAPS and assigned the shift in part to the hostility from the community and the media. References to increased emotional "hardness", and feelings of sadness, despondency, low motivation, and helplessness by police officers and the psychologists' references to low levels of self-esteem and morale, emotional bluntness, and a lack of self-belief among police officers, all suggest that the sense of self amongst police officers (both those interviewed by the researchers and those encountered by police psychologists) has been negatively affected. Associated with this is the psychological isolation from their communities that officers experience as a result of verbal and physical abuse as well as the lack of assistance provided by communities to police officers.

It is also noteworthy that police officers did not perceive parts of the community as hostile towards them. Officers appeared to perceive the rejection as absolute, thus making a negative impact on the sense of self more likely (Rosenberg, 1979; Shrauger \& Schoeneman, 1979). Most police officers seeemed to accept that some hostility toward the police is inevitable but also expressed disbelief at the complete lack of cooperation from members of the community. Officers also resented the high degree of subservience that they are expected to deliver to the public (see also Gaines \& Jermier, 1983) and the frequent attacks by the media on the quality of their work; findings that are similar to those of White, Lawrence, Biggerstaff, and Grubb (1985) (see also Brown \& Campbell, 1990, 1994; Flanagan \& Vaughn, 1996). Similar to Fischer's (1984) findings, these results indicate an intense disturbance of the police officers' sense of social order and sense of community. The belief that there exist shared values and beliefs between officers and the broad community appears to have been undercut. It is important to note that the feelings toward self and society are characterised by more than mere ambivalence which, according to Crocker and Major (1989), is in itself indicative of a negatively affected sense of self. The attitude toward self, community, society, and organisation is actively negative rather than merely indifferent.

Overall, officers were characterized as experiencing paranoia, defensiveness and a general sense of abandonment. As such these findings are in line with the conclusion drawn by Beutler, Nussbaum, and Meredith (1988) that "police service is associated 
with adverse psychological changes among officers" (p. 506) and those of Patterson (1989), and Violanti and Marshall (1983) who noted a shift toward a more cynical attitude toward life among police officers.

\section{Self-Consistency}

For at least half of the officers interviewed, negative social feedback also appears to have resulted in an inconsistent sense of self. References to work behaviour and cognition that are discrepant from those engaged in when away from work suggest that these individuals have not attained a congruent or stable view of themselves. The structure of the self is not characterised by consistency across time and situation, a finding that supports the notion of the contextual nature of the self (Markus \& Wurf, 1987; Turner \& Onorato, 1999; Rhodewalt \& Agustsdottir, 1986) and the "self-with-other" idea of Andersen, Reznik, and Chen (1997). The "inner unity" (Harre, 1987, p. 42) is thus absent, resulting in the possible breakdown of the identity structure (Rosenberg \& Gara, 1985, p. 90). One officer's reference to having a "split-personality" also indicates an inability to maintain a consistent set of behaviours or cognitions. This splitting of the self, also noted by authors ranging from James (1890) to Bruner and Kalmar (1998), Elliot (1986), Strasser (1984), and Scheier and Carver (1983), has been linked to feelings of emptiness, selfdestructiveness, withdrawal of emotional life, deep feelings of unhappiness, and the reckless pursuit of desire; similar to some of the issues which police psychologists reported police officers to be experiencing. The absence of adequate social support makes the splitting of the self even more likely (Allen \& van de Vliert, 1984; Boyanowsky, 1984; Elliot, 1986; Bruner \& Kalmar, 1998).

In particular it would appear that the work self is not only characterised by a greater degree of negative emotion and behaviour but that the non-work self expresses many of the emotions that are built-up at work. This "carry-over effect" (Jones, Berglas, Rhodewalt, \& Skelton, 1981) may occur when individuals are unable to disengage from their "working selves" and carry the associated behaviour and cognitive patterns over into an environment in which they are no longer appropriate. These emotions remain unexpressed at work due not only to a culture of repressive coping but also due to the fact that police work does not allow the expression of emotion as and when it is evoked (Alkus \& Padesky, 1980; Elison \& Buckhout, 1981; Melville, 1999; Mulcahy, 1995; Munshi, 1998; Reiser \& Geiger, 1989; Sandler, 1989; Violanti, 1992; and Violanti \& Aron, 1994). This may also account for the high incidence of spousal abuse noted by the psychologists.

\section{An Absence of Support}

The most pervasive finding was the impact that the lack of support from supposed allies has on police officers. Officers, without exception, believe that there is an absence of support from "significant others" such as government, police management, co-workers, the courts, and the media. In addition to the perceived absence of support there is a simultaneous perceived presence of negative regard from these groups. The majority of the officers indicated that they felt abandoned and betrayed by these "significant others" whose approval and support is important to the police officer. It is likely that negative regard from the community could, at least in part, be discounted if juxtaposed with perceived support from management, an accommodating organisational culture, and sound, supportive relationships with other important interaction partners such as the courts and government. In the absence of such support and the presence of criticism from these quarters, the negative feedback received from the community appears to be validated inasmuch as it appears to be consensual across the entire spectrum of interaction partners.

\section{CONCLUSION}

Changes in the officers' view of themselves and the social world in which they are located suggest a fundamentally negative shift in their sense of self. The loss of respect for themselves, the SAPS, the community and society in general indicated by police officers suggests a profound shift in the way in which they perceive the world. The suggestion that working conditions have caused this negative shift is supported by the fact that almost all police officers indicated that they had joined the police force with a great degree of optimism, motivation, commitment, and desire to serve the community (see also Berold, 1999). A lack of continuous validation prevents the maintenance of this positive sense of self (Rosenberg, 1979; Dodds, Lawrence, \& Valsiner, 1997). The positive self has thus been replaced by one that is cynical and negative toward work, the organisation, and the communities which the individual serves. The continuous nature of the negative feedback makes negative information about the self far more accessible to the individual, particularly when he/she is located in the environment in which the negative feedback occurs.

This negative impact on the self at work is of particular concern given that for most of the police officers who participated in this study, police work is perceived as a superordinate role (Rosenberg \& Gara, 1979). Individuals tend to seek a sense of purpose, social relationships, and an enhancement of the self-concept from work (Locke \& Taylor, 1990; Nord, Brief, Atieh, \& Doherty, 1990) however these needs appear to be frustrated in the environment in which they work. It is likely that many of the well-documented problems evident in the relationship between police and community as well as the low levels of psychological well-being of police officers in South Africa can, in part, be traced back to the presence of consensual negative feedback and the absence of positive feedback in their working lives.

\section{REFERENCES}

Albert, K. (1978). The police and their image: a comparative study of the American and cape town policemen. Unpublished master's thesis. University of Cape Town, South Africa.

Alkus, S., \& Padesky, C. (1980). Special problems of police officers: stress related issues and interventions. The Counselling Psychologist, 11, 55-64.

Allen, V.L., \& van de Vliert, E. (1984). A role theoretical perspective on transitional processes. In V.L. Allen, \& E. Van de Vliert (Eds.), Role transitions (pp. 32-49). New York: Plenum Press.

Alloy, L.B., \& Lipman, A.J. (1992). Depression and selection of positive and negative social feedback: motivated preference or cognitive balance? Journal of Anormal Psychology, 101, 310-313.

Allport, G. (1979). The nature of prejudice. New York: Doubleday Anchor Books.

Altenroxel, L. (April 21, 1999). Assaults at scene of crime "common" says researcher. The Cape Times.

Andersen, S.M., Reznik, I., \& Chen, S. (1997). The self in relation to others: cognitive and motivational underpinnings. In J.G. Snodgrass, \& R.L. Thompson (Eds.), The self across psychology (pp.233-275). New York: The New York Academy of Sciences.

Anson, R.H., \& Bloom, M.E. (1988). Police stress in an occupational context. Journal of Police Science and Administration, 16, 229-235.

Anstey, M., \& Stanley, N. (1994). Grassroots perceptions of transformation in the SAPS; findings from a pilot study in the Eastern Cape. Labour Relations Research and Topics Series No 24. Labour Research Unit, University of Port Elizabeth: Port Elizabeth.

Baumeister, R.F. (1982). A self-presentational view of social phenomena. Psychological Bulletin, 91, 3-26. 
Baumeister, R.F., \& Tice, D.M. (1990). Anxiety and social exclusion. Journal of Social and Clinical Psychology, 9, 165-195.

Baumgardner, A.H., Kaufman, C.M. \& Cranford, J.A. (1990). To be noticed favourably: links between private self and public self. Personality and Social Psychology Bulletin, 16, 705-716.

Beehr, T.A., Johnson, L.B., \& Nieva, R. (1995). Occupational stress: coping of police and their spouses. Journal of Organisational Behaviour, 16, 3-25.

Belson, W.A. (1975). The public and the police. London: Harper $\&$ Row.

Berold, S. (1999). Police and well-being. Unpublished honours thesis. University of Cape Town, South Africa.

Beutler, L.E., Nussbaum, P.D., \& Meredith, K.E. (1988). Changing personality patterns of police officers. Professional Psychology: Research and Practice, 19, 503-507.

Blaikie, N. (1993). Approaches to social enquiry. Cambridge: Polity Press.

Bohrnstedt, G.W., \& Felson, R.B. (1983). Explaining the relations among children's actual and perceived performances and self-esteem: a comparison of several causal models. Journal of Personality and Social Psychology, 45, 43-56.

Boyanowsky, E.O. (1984). Self-identity change and the role transition process. In V.L. Allen, \& E. Van de Vliert (Eds.). Role transitions (pp. 34-51). New York: Plenum Press.

Brief, A.P., \& Nord, W.R. (1990). Work and meaning: definitions and interpretations. In Brief \& Nord (Eds.), Meanings of occupational work: a collection of essays (pp. 1-19). Lexington: Lexington Books.

Brown, J.M., \& Campbell, E.A. (1990). Sources of occupational stress in the police. Work and Stress, 4, 305-318.

Brown, J.M., \& Campbell, E.A. (1994). Stress and policing: sources and strategies. Chichester: John Wiley \& Sons.

Bruner, J. (1997). A narrative model of self-construction. In J.G. Snodgrass, \& R.L. Thompson (Eds.), The self across psychology (pp.145-161). New York: The New York Academy of Sciences.

Bruner, J., \& Kalmar, D.A. (1998). Narrative and meta-narrative in the construction of self. In M. Ferrari, \& R.J. Sternberg (Eds.), Self-awareness: its nature and development. (pp.308-331). New York: The Guilford Press.

Burgers, T.J. (1994). Facing the enemy. Indicator South Africa, 12, 5-8.

Burke, R.J. (1987). Burnout in police work: an examination of the Cherniss model. Group and Organisation Studies, 12, 174-188.

Burke, R.J. (1993). Toward an understanding of psychological burnout among police officers. Journal of Social Behaviour and Personality, 8, 425-438.

Burr, V. (1995). An introduction to social constructionism. London: Routledge.

Campbell, J.D., \& Lavallee, L.F. (1993). Who am I? The role of self-concept confusion in understanding the behaviour of people with low self-esteem. In R.F. Baumeister (Ed.), Selfesteem: the puzzle of low self regard (pp. 3-20). New York: Plenum Press.

Casey, C. (1995). Work, self, and society. London: Routledge.

Cheek, J.M., \& Hogan, R. (1983). Self-concepts, selfpresentations, and moral judgments. In J.Suls, \& A.G. Greenwald (Eds.). Psychological perspectives on the self: volume 2 (pp. 74-94). Hillsdale: Lawrence Erlbaum Associates.

Coleman, M. (1999). A crime against humanity: analysing the repression of the apartheid state. Cape Town: David Philips Publishers.

Cook, H. (1986). Mamelodi: South Africa's response to peaceful protest. Washington: Lawyer's Committee for Human Rights.

Cooley, C.H. (1902). Human nature and the social order. New York: Scribner.

Creswell, F. (April 20, 1999). World views SAPS brutality. The Cape Times.
Crocker, J. \& Blanton, H. (1999). Social inequality \& self-esteem: the moderating effects of social comparison, legitimacy, and contingencies of self-esteem. In T.R. Tyler, R.M. Kramer, \& O.P. John (Eds.), The psychology of the social self (pp. 171-191). Mahwah: Lawrence Erlbaum Associates Inc.

Crocker, J., \& Major, B. (1989). Social stigma and self-esteem: the self-protective properties of stigma. Psychological Review, 96, 608-630.

Dodds, A.E., Lawrence, J.A., \& Valsiner, J. (1997). The personal and the social: Mead's theory of the 'generalised other'. Theory and Psychology, 7, 483-503.

Doherty, K. \& Schlenker, B.R. (1991). Self-Consciousness and strategic self-presentation. Journal of Personality, 59, 1-18.

Dressler, W.W. (1988). Social consistency and psychological distress. Journal of Health and Social Behaviour, 29, 79-91.

Elison, K.W., \& Buckhout, R. (1981). Psychology and criminal justice. New York: Harper \& Row.

Elliot, G.C. (1986). Self-esteem and self-consistency: a theoretical and empirical link between two primary motivations. Social Psychology Quarterly, 49, 207-218.

Ensor, L. (January 8, 1999). Cape police performance "pitiful". Business Day.

Felson, R.B. (1989). Parents and the reflected appraisal process: a longitudinal analysis. Journal of Personality and Social Psychology, 56, 965-971.

Felson, R.B. (1993). The (somewhat) social self: how others affect self-appraisals. In J. Suls (Ed.) Psychological perspectives on the self: volume 4 (pp. 1-26). London: Lawrence Erlbaum.

Fischer, C.T. (1984). A phenomenological study of being criminally victimized. Journal of Social Issues, 40, 161-178.

Flanagan, T.J., \& Vaughn, M.S. (1996). Public opinion about police use of force. In W.A. Geller, \& H. Toch (Eds.), Police Violence (pp. 113-128). New Haven: Yale University Press.

Freeman, M. (1993). Rewriting the self: history, memory, narrative. London: Routledge Publishers.

Friedman, R. (May 6, 1999). Judge hauls police over coals. The Cape Times.

Gaines, J., \& Jermier, J.M. (1983). Emotional exhaustion in a high stress organisation. Academy of Management Journal, 26, 567-586.

Gergen, K.J. (1965). The effects of interaction goals and personalistic feedback on the presentation of self. Journal of Personality and Social Psychology, 1, 413-424.

Gergen, K.J. (1971). The concept of self. New York: Holt, Rhinehart and Winston Inc.

Gifford, G. (May 19, 1999). Charge police for brutality probe findings. The Star.

Gilbert, D.T. \& Jones, E.E. (1986). Exemplification: the selfpresentation of moral character. Journal of Personality, 54, 593-615.

Girodo, M. (1984). Entry and re-entry strain in undercover agents. In V.L. Allen, \& E. Van de Vliert (Eds.). Role transitions (pp. 167-191). New York: Plenum Press.

Goffman, E. (1959). The presentation of self in everyday life. Garden City: Doubleday/Anchor.

Goko, J. (November 15, 1999). Two out of three have no faith in police says survey. Business Day.

Goldstone, R. (1994). Commission of inquiry regarding the prevention of public violence and intimidation: final report on attacks on members of the SAP.

Gophe, M. (November 2, 1999). Racism stil in full force - city police. Argus.

Hageman, M.J.C. (1982). Responses of police rookie officers to stress. Journal of Police Science and Administration, 10, 235-243.

Harre, R. (1987). The social construction of selves. In K.Yardley, $\&$ T.Honess (Eds.) Self and identity: psychosocial perspectives (pp. 41-52). Chichester: John Wiley \& Sons.

Hirsch, B.J., \& Jolly, E.A. (1984). Role transitions and social networks: social support for multiple roles. In V.L. Allen, \& E. Van de Vliert (Eds.). Role transitions. New York: Plenum Press. 
Hochschild, A.R. (1983). The managed heart: the commercialisation of human feeling. Berkeley: University of California Press.

Hoorens, V. (1995). Self-favouring biases, self-presentation, and the self-other asymmetry in social comparison. Journal of Personality, 63, 800-818.

Hortacsu, N. (1989). Turkish students' self concept and reflected appraisals of significant others. International Journal of Psychology, 24, 451-463.

Hulin, C.L. (2002). Lessons from industrial and organisational psychology. In J.M. Brett \& F Drasgow (Eds.) The psychology of work. (pp.3-23). London: Lawrence Erlbaum Associates.

James, W. (1890). The principles of psychology. New York: Holt.

Jones, E.E., Berglas, S., Rhodewalt, F, \& Skelton, J.A. (1981). Effects of stratgic self-presentation on subsequent selfesteem. Journal of Personality and Social Psychology, 41, 407-421.

Jones, S.C. (1973). Self and interpersonal evaluations: esteem theories versus consistency theories. Psychological Bulletin, 79, 185-199.

Jussim, L., Brown, R., Soffin, S., Ley, J., \& Kohlhepp, K. (1992). Understanding reactions to feedback by integrating idea from symbolic interactionism and cognitive evaluation theory. Journal of Personality and Social Psychology, 62, 402-421.

Jussim, L., Yen, H., \& Aiello, J.R. (1995). Self-consistency, selfenhancement, and accuracy in reaction to feedback. Journal of Experimental Social Psychology, 31, 322-356.

Kaplan, H.B. (1975). Self-attitudes and deviant behaviour. California: Goodyear Publishers.

Kimmel, A.J. (1988). Ethics and values in applied social research. Newbury Park: Sage Publications.

King, N. (1994). The qualitative research interview. In C. Cassell, \& G. Symon (Eds.), Qualitative methods in organisational research: a practical guide. (pp. 15-36). London: Sage Publications.

Koopman, A. (May 20, 1999). "We can't cope" say police. The Cape Times.

Kotlolo, M. (January 12, 1999). Black student cops complain about lack of transformation. The Sowetan.

Kramer, R.M., \& Wei, J. (1991). Social uncertainty and the problem of trust in social groups: the social self in doubt. In T.R. Tyler, R.M. Kramer, \& O.P. John (Eds.), The psychology of the social self (pp. 145-168). Mahwah: Lawrence Erlbaum Associates Inc.

Kvale, S. (1996). Interviews: an introduction to qualitative research interviewing. Thousand Oaks: Sage Publications.

Leary, M.R., \& Atherton. S.C. (1986). Self-efficacy, social anxiety, and inhibition in interpersonal encounters. Journal of Social and Clinical Psychology, 4, 256-267.

Leary, M.R., (1990). Responses to social exclusion: social anxiety, jealousy, loneliness, depression, and low-self-esteem. Journal of Social and Clinical Psychology, 9, 221-229.

Levi, L. (1981). Society, stress, and disease. New York: Oxford University Press.

Locke, E.A., \& Taylor, M.S. (1990). Stress, coping, and the meaning of work. In Brief \& Nord (Eds.), Meanings of occupational work: a collection of essays (pp. 140-157). Lexington: Lexington Books.

Lopez, E.M. (1982). A test of the self-consistency theory of the job performance - job satisfaction relationship. Academy of Management Journal, 25, 335-348.

Maddux, J.E., Norton, L.W., \& Leary, M.R. (1988). Cognitive components of social anxiety: an investigation of the integration of self-presentation theory and self-efficacy theory. Journal of Social and Clinical Psychology, 6, 180-190.

Makgalemele, T. (April 3, 1999). Braving death to serve. The Star.

Maluleke, E. (February 28, 1999). "Beware you kaffir cops". City Press.

Marks, M. (1995). Stresses in the South African police services. Johannesburg: Centre for the Study of Violence and Reconciliation.
Markus, H. \& Wurf, E. (1987). The dynamic self-concept: a social psychological perspective. Annual Review of Psychology, 38, 299-337.

McCall, G.J. (1987). The structure, content,and dynamics of self: continuities in the study of role identities. In K.Yardley, \& T.Honess (Eds.) Self and identity: psychosocial perspectives (pp. 132-147). Chichester: John Wiley \& Sons.

McCrae, R.R. (1982). Consensual validation of personality traits: evidence for self-reports and ratings. Journal of Personality and Social Psychology, 43, 293-303.

Mead, G.H. (1934). Mind, self, and society. University of Chicago Press: Chicago

Melville, N.J. (1999). The taming of the blue: regulating police misconduct in South Africa. Pretoria: HSRC.

Merten, M. (2000). Cops down a dop to beat the stress. Mail and Guardian, January 21-27, 40.

Miles, M.B., \& Huberman, A.M. (1994). Qualitative data analysis. Thousand Oaks: Sage Publications.

Mishler, E.G. (1986). Research interviewing: context and narrative. Cambridge: Harvard University Press.

Moreland, R.L., \& Sweeney, P.D. (1984). Self-expectancies and reactions to evaluations of performance. Journal of Personality, 82, 213-225.

Mulcahy, A. (1995). "Headhunter" or "real cop": identity in the world of internal affairs officers. Journal of Contemporary Ethnography, 24, 99-130.

Munshi. A. (1998). An exploratory study of the perceptions of stress and trauma among police officers and helping professions in the Western Cape. Unpublished Thesis: University of Cape Town

Nathan, L. (1989). Troops in the townships, 1984-1987. In J. Cock, \& L. Nathan (Eds.) War and society: the militarisation of South Africa (pp. 65-72). Cape Town: David Philip.

Nel, J. \& Steyn, M. (1996). Safety and security and mental health In D. Foster, M. Freeman, \& Y. Pillay (Eds.), Mental health policy issues for South Africa (pp. 316-329). Cape Town: Multimedia Publications

Neikrug, S. (1982). Meaning in work toward a clinical approach to work dissatisfaction. Journal of Sociology and Social Welfare, 9, 134-145.

Nezlek, J.B., Kowalski, R.M., Leary, M.R., Blevins, T., \& Holgate, S. (1997). Personality moderators of reactions to interpersonal rejection: depression and trait self-esteem. Personality and Social Psychology Bulletin, 23, 1235-1244.

Nord, W.F., Brief, A.P., Atieh, J.M., \& Doherty, E.M. (1990). Studying meaning of work: the case of work values. In Brief \& Nord (Eds.), Meanings of occupational work: a collection of essays (pp. 21-64). Lexington: Lexington Books.

Nxusani, N. (November 18, 1998). 1090 cops killed in South Africa since 1994. The Sowetan.

O'Brien, G.E. (1992). Changing meanings of work. In J.F. Hartley, \& G.M. Stephenson (Eds.), Employment relations (pp. 44-66). Oxford: Blackwell Publishers.

Oyserman, D., \& Markus, H.R. (1993). The sociocultural self. In J. Suls (Ed.) Psychological perspectives on the self: volume 4 (pp. 187-220). London: Lawrence Erlbaum.

Patterson, B.L. (1989). Job experience and perceived job stress among police, correctional, and probations/parole officers. Criminal Justice and Behaviour, 19, 160-285.

Pelham, B.W., \& Hetts, J.J. (1999). Inplicit and explicit personal and social identity: toward a more complete understanding of the social self. In T.R. Tyler, R.M. Kramer, \& O.P. John (Eds.). The psychology of the social self (pp. 1-35). London: Lawrence Erlbaum Associates.

Pestonjee, D.M. (1992). Stress and coping: the Indian experience. London: Sage Publications.

Rauch, J., Levin, N., Lue, M., \& Ngubeni, K. (1995). Creating a new South African police service. South Africa: Centre for the Study of Violence and Reconciliation.

Reiser, M., \& Geiger, S.P. (1989). Police officers as victim. Professional Psychology: Research and Practice, 15, 315-323. 
Rhodewalt, F. \& Agustsdottir, S. (1986). Effects of selfpresentation on the phenomenal self. Journal of Personality and Social Psychology, 50, 47-55.

Rosenberg, M. (1979). Conceiving the self. Malabar: Robert E. Krieger Publishing Company.

Rosenberg, S., \& Gara, M.A. (1985). The multiplicity of personal identity. In P. Shaver (Ed.) Self, situations, and social behaviour (pp. 87-114). London: Sage Publication.

Rosenberg. M. (1981). The self-concept: social product and social force. In M.Rosenberg, \& R.H. Turner (Eds.) Social psychology: sociological perspectives (pp.593-624). New York: Basic Books.

Salovey, P., \& Rodin, J. (1985). Cognitions about the self. In P. Shaver (Ed.) Self, situations, and social behaviour (pp. 143166). London: Sage Publication.

Sandler, D. (1989). The psychological experience of white conscripts in the black townships. In J. Cock, \& L. Nathan (Eds.), War and society: the militarisation of South Africa (pp. 79-89). Cape Town: David Philip.

Schafer, R.B., \& Keith, P.M. (1999). Change in adult self-esteem: a longitudinal assessment. British Journal of Social Psychology, 38, 303-314.

Scheier, M.F., \& Carver, C.S. (1983). Two sides of the self:one for you and one for me. In J.Suls, \& A.G. Greenwald (Eds.). Psychological perspectives on the self: volume 2 (pp. 151-171). Hillsdale: Lawrence Erlbaum Associates.

Schlenker, B.R., \& Leary, M.R. (1982). Social anxiety and selfpresentation: a conceptualisation and model. Psychological Bulletin, 92, 641-669.

Schronen, J. (January 7, 1999a). Crimebusting shambles. The Argus.

Schronen, J. (May 20, 1999b). "Pimps in uniform" row hits city cops. The Argus.

Shamir, B. (1986). Self-esteem and the psychological impact of unemployment. Social Psychology Quarterly, 49, 61-72.

Sheer, V.C., \& Weigold, M.F. (1995). Managing threats to identity: the accountability triangle and strategic accounting. Communication Research, 22, 592-611.

Sheeran, P., \& Abraham, C. (1994). Unemployment and selfconception: a symbolic interactionist analysis. Journal of Community and Applied Social Psychology, 4, 115-129.

Shotter, J. (1983). Social accountability and selfhood. New York: Basil Blackwell Publishers.

Shrauger, J.S., \& Schoeneman, T.J. (1979). Symbolic interactionist view of the self-concept: through the looking glass darkly. Psychological Bulletin, 86, 549-573.

Schreuder, A. \& Theron, A. (1997). Careers: An Organisational Perspective. Cape Town: Juta.

Sigler, R.T. \& Wilson, C.N. (1988). Stress in the work place: comparing police stress with teacher stress. Journal of Police Science and Administration, 16, 151-162.

Spencer, S.J., Josephs, R.A., \& Steele, C.M. (1993). Low selfesteem: the uphill struggle for self-integrity. In R.F. Baumeister (Ed.), Self-esteem: the puzzle of low self-regard (pp. 21-36). New York: Plenum Press.
Steinberg, J. (June 11, 1999). Racism prevalent in police, say black forum. Business Day,

Stradling, S.G., Crowe, G., \& Tuohy, A.P. (1993). Changes in the self-concept during occupational socialization of new recruits to the police. Journal of Community and Applied Social Psychology, 3, 131-147.

Strasser, H. (1984). Status inconsistency through role transitions: toward a systematic attempt to explain causes and patterns of individual reactions. In V.L. Allen, \& E. Van de Vliert (Eds.) Role transitions. New York: Plenum Press.

Strauss, A.L. (1997). Mirrors and masks: the search for identity. New Brunswick: Transaction Publishers.

Swann, W.B., \& Read, S.J. (1981). Self-verification processes: how we sustain our self-conceptions. Journal of Experimental Social Psychology, 17, 351-372.

Swann, W.B., Griffin, J.J., Predmore, S.C., \& Gaines, B. (1987). The cognitive-affective crossfire: when self-consistency confronts self-enhancement. Journal of Personality and Social Psychology, 52, 881-889.

Sweeney, P.D., \& Wells, L.E. (1990). Reactions to feedback about performance: a test of three competing models. Journal of Applied Social Psychology, 17, 1119-1128.

Thoits, P.A. (1985). Self-labeling processes in mental illness: the role of emotional deviance. American Journal of Sociology, 91, 221-249.

Turner, J.C., \& Onorato, R.S. (1999). Social identity, personality, and the self-concept: a self-categorization perspective. In T.R. Tyler, R.M. Kramer, \& O.P. John (Eds.), The psychology of the social self (pp. 11-46). London: Lawrence Erlbaum Associates.

Van de Vliert, E. (1984). Role transitions as interrole conflict. In V.L. Allen, \& E. Van de Vliert (Eds.). Role transitions. New York: Plenum Press.

Van Eyk, M. (1993). The principles and problems of policing in South Africa. In M.L. Mathews, P.B. Heymann, \& A.S. Mathews. Policing the conflict in South Africa. Gainesville: University Press of Florida.

Violanti, J.M. (1992).Coping strategies among police recruits in a high-stress environment. Journal of Social Psychology, 132, 717-729.

Violanti, J.M., \& Aron, F. (1994). Ranking police stressors. Psychological Reports, 75, 824-826.

Violanti, J.M.,\& Marshall, J.R. (1983). The police stress process. Journal of Police Science and Administration, 11, 389-394.

Vogel, J. (February 27, 1999). The darker side of police work. The Star.

Wallace, P.A., Roberg, R.R., \& Allen, H.E. (1985). Job burnout among narcotics investigators: an exploratory study. Journal of Criminal Justice, 13, 549-559.

Waters, L.K., \& Martelli, J. (1989). The police stress survey: reliability and relation to job satisfaction and orgnizational commitment. Psychological Reports, 64, 267-273.

White, J.W., Lawrence, P.S., Biggerstaff, C., \& Grubb, T.D. (1985). Factors of stress among police officers. Criminal Justice and Behaviour, 12, 111-128. 